\title{
Rural Development Scheme: A Case Study on Islami Bank Bangladesh Limited
}

\author{
K. M. Anwarul Islam \\ Department of Business Administration, The Millennium University, Dhaka, Bangladesh \\ Email address: \\ ai419bankingdu@gmail.com (K. M. A. Islam)
}

\section{To cite this article:}

K. M. Anwarul Islam. Rural Development Scheme: A Case Study on Islami Bank Bangladesh Limited. International Journal of Finance and Banking Research. Vol. 2, No. 4, 2016, pp. 129-138. doi: 10.11648/j.ijfbr.20160204.12

Received: January 23, 2016; Accepted: May 17, 2016; Published: June 30, 2016

\begin{abstract}
Islami Bank Bangladesh Limited (IBBL) has introduced "Rural Development Scheme" in 1995 to cater to the investment needs of the agriculture and rural sector of the country to create opportunity for employment and raising income of the rural people. The authority of RDS should increase the size of investment in order to cope with the change in value of currency because of inflation and other economic reasons. RDS should project their volume of activities for future; then all parties involving in managing RDS should be assigned and held responsible for the job assigned at the beginning of the year. In this research paper examines the performance of RDS should be subject to Balanced Score Card System. RDS with its differentiated features can lock more market share in the country if it comes out with more generous policy like selection of people not on religions basis.
\end{abstract}

Keywords: RDS, Poverty Alleviation, IBBL

\section{Introduction}

\subsection{Background of the Research}

Bangladesh with its $38 \%$ people living below poverty line and $18 \%$ living in absolute poverty is suffering from acute rural-urban economic disparity coupled with illiteracy, lack of proper health and sanitation facilities. The country's economy is basically an agrarian one with vast majority living in rural areas. The agriculture sector is unable to provide any further scope for employment resulting in influx of rural population towards urban areas. Rural areas are characterized by stagnant agriculture and scanty industries. Underemployment and unemployment is a regular phenomenon particularly in rural areas. The vast human resources have remained unutilized due to lack of education, proper training and concerted efforts to help grow the rural economy. It results in uneven distribution of income which causes serious setback in balanced geographical growth as well as growth of GDP. Islami Bank Bangladesh Limited was founded with the major objective of establishing Islamic economy for balanced economic growth by ensuring reduction of rural-urban disparity and equitable distribution of income. In view of the above, Branches of the Bank have been encouraged to invest their deposits in their respective areas and in particular for the economic uplift of the rural people. Accordingly, a Scheme in the name and style of 'Rural Development Scheme' has been introduced in 1995 to cater to the investment needs of the agriculture and rural sector to create opportunity for generation of employment and raising income of the rural people with a view to alleviate poverty. It is treated as first Islamic Microfinance Model in the Country \& abroad.

\subsection{Overview of Rural Development Scheme}

\subsubsection{Rural Development Scheme}

Rural Development Scheme is a socio-economic venture of IBBL. This program has been introduced for enhancing the socio-economic conditions of poor people living in abject poverty. This also enhances moral, social and ethical values of these poor people of the country. In fact, this program is bringing poor people into the main stream of economy by getting them involved into different farm and non-farm activities in the rural area. These pictures of RDS have been drawn in the following paragraphs:

\subsubsection{Features of Rural Development Scheme}

Rural Development Scheme is based on ideals and 
teachings of ISLAM which is totally different from traditional micro credit systems of thousands of NGOs and GOs. Here described the differentiated features of RDS. That is, RDS can be differentiated from any traditional microcredit programs with respect to the stated differentiated features as above. There are similarities between RDS and traditional micro-credit programs with respect to group size $\&$ formation, frequency of meeting, mode of payment, duration of loan, coverage, single loan exposure etc.

\subsubsection{Analysis of Growth Performance of Rural Development Scheme}

Growth is one of the important strategies for enhancing the sustainability of any business model. Growth indicates both past and future performance of the model. This is why the study has examined the growth of some important variables such as coverage-area and members, investment activities, deposit of member participants and recovery rate. The study has recourse to geometric mean for determining growth of aforesaid variables over the 8 year periods from 2008 to 2015 . Besides, the growth performance has been judged by descriptive statistical measures-mean, standard deviation and limits in order to see whether the growth in respective parameter is accomplished as result of boom period/recession period or efficient performance of RDS on a continuous basis over the study periods.

\subsubsection{Rural Development Scheme of Islami Bank Bangladesh Limited (IBBL)}

Islami Bank Bangladesh Limited (IBBL) launched a shariah based Microfinance program named Rural Development Scheme (RDS) in 1995, to uplift the overall socioeconomic plight of the rural poor. Presently, some 0.52 million group members of which 94 percent are female, are involved in this scheme. Before further expansion into new areas, an assessment of the achievement of the RDS and its impact on the livelihood of the rural people was required. To conduct this study, primary data were collected interviewing 1020 randomly selected RDS clients working across the country. The study analyzed many facets of the RDS and concludes that it was generally a success. Household income and expenditure had increased significantly and clients had a positive opinion towards the micro investment program as it improved their standards of living. The study recommends that RDS activities be extended towards hardcore poor, especially for widows and divorcees. Monitoring and supervision should be strengthened, while more ethical and moral motivational programs have to be undertaken for both field supervisors and clients to reduce shariah violation. The program can be replicated in other rural areas of Bangladesh in order to accelerate economic activities of the poor.

\subsubsection{IBBL Observes 30 Years of Rural Development Scheme}

Islami Bank Bangladesh Limited (IBBL) is endeavoring to establish a society based on equity and justice following the lofty ideals of Islamic Shariah. The bank has, in line with the said objective, introduced Rural Development Scheme in
1995 to cater to the investment needs of the agriculture and rural sector of the country to create opportunity for employment and raising income of the rural people. The Scheme has been aimed at achieving an integrated development in rural areas and gradually developing model village. By this time, the scheme expanded its operations through 183 branches of the bank in 13,373 villages of the country under 372 thanas of 61 districts. The rural poor are provided with investment facility in agriculture and 343 selected off-farm economic activities in the rural areas starting from Tk 10,000 to a maximum limit of Tk 3,00,000. The amount of cumulative disbursement through this scheme stood at Tk 45086.32 million within the 6, 24,591 investment clients up-to February 2012. Rate of recovery against the running investment is 99 per cent. Besides the investment activities, successful members, so far, have been provided 8,954 no of tube-wells with amounting Tk 17.71 million and 4,746 sanitary latrines amounting Tk 5.60 million on Quarde-Hasana (profit-free investment) as a part of health and sanitation program of the scheme.

\subsubsection{The Main Objectives of the Scheme Are}

- To extend investment facilities to agricultural, other farming and off-farming activities in the rural areas

- To finance self-employment and income generating activities of the rural people, particularly the rural unemployed youths and the rural poor.

- To alleviate rural poverty through integrated rural development approach.]

- To extend investment facilities for hand tube-wells and rural housing, keeping in view the needs of safe drinking water and housing facilities of the rural dwellers.

To provide education and Medicare facilities to the downtrodden people.

\subsubsection{Integrated Development Approach}

The purpose of the Scheme is not only providing Micro Investment facilities to the stake- holder but also ensure various types of facilities \& services to the downtrodden people as a part of Integrated Development Approach as well as Corporate Social Responsibility. The following areas have been covered under the Scheme:

- Humanitarian Assistance Program.

- Education Program.

- Capacity building or Training Program

- Health \& Medicare Program

- Environment protection Program.

\subsubsection{Target Area}

- Initially the Scheme was started as a Pilot Scheme in the rural areas of certain districts under the direct supervision of the nearby Branches of the Islami Bank Bangladesh Limited.

- The Scheme is being gradually extended to all the Districts through different Branches of the Bank. 


\subsubsection{Command Area and Baseline Survey}

Each designated Branch \& SME/Krishi Branch selects villages within a radius of 10 kilometers of the Branch premises. Following criteria is being followed in selecting a village:

- Easy communication;

- Availability of agriculture and other off-farm activities;

- Abundance of low-income people;

After primary selection of a research area consisting of 4 to 6 villages, Branch conducts detailed Baseline Survey to identify the target group people and the varieties of economic activities in those areas. The concerned Branch has to ensure the availability of at least 400 target group people in the selected area.

\subsubsection{Target Group}

- Able bodied \& industrious rural poor having age between 18 to 50 years and the permanent resident of the research area.

- $\quad$ Farmers having cultivable land maximum 0.50 acres and the Sharecroppers.

- Persons engaged in very small off-farm activities in the rural areas

- Destitute women and distressed people

- Persons having liabilities with other banks/institutions are not eligible for investment under the Scheme.

\subsubsection{Command Area and Baseline Survey}

Each designated Branch \& SME/Krishi Branch selects villages within a radius of 10 kilometers of the Branch premises. Following criteria is being followed in selecting a village:

- Easy communication;

- Availability of agriculture and other off-farm activities;

- Abundance of low-income people;

After primary selection of a research area consisting of 4 to 6 villages, Branch conducts detailed Baseline Survey to identify the target group people and the varieties of economic activities in those areas. The concerned Branch has to ensure the availability of at least 400 target group people in the selected area.

\section{Literature Review}

Laura Ryser and Greg Halseth(2010) Rural Economic Development: A Review of the Literature from Industrialized Economies: Over the past 30 years, accelerating change has been one of the defining attributes of rural landscapes around the world. In response, there has been an increasing volume of rural economic development research and public/policy interest in that research. The purpose of this review article is not to provide a 'state of the literature' summary, but rather to highlight thematic directions, opportunities, and trends in the rural economic development literature over the past decade in industrialized economies. We review many of the longstanding research themes in rural economic development research: social and economic restructuring, barriers and challenges to economic development, community economic development, community capacity, governance, and policies and programs. We also explore a range of research issues that have (re-) emerged over the past decade focusing on new approaches to understanding rural change and the deployment of development strategies in the context of the new rural economy

Robert Chapman, Tom Slaymaker (2002) ICTs and Rural Development: Current Interventions and Opportunities for Action This paper explore the role of information and communication technologies (ICTs) in developing countries. It focuses on rural areas least affected by the advances in the 'digital revolution' and looks beyond the 'digital divide' debate to assess the potential role of ICTs in the context of rural development paradigms. The authors address the divergence between the technology drivers and the potential beneficiaries in rural areas in developing countries, as well as the opportunities arising from the continued convergence of old and new ICTs. They consider alternative approaches to harness ICTs for development goals including private sector, public sector and NGO-based initiatives.

Sophal Ear (2012) Towards Effective Emerging Infectious Diseases Surveillance: Evidence from Kenya, Peru, Thailand, and the US-Mexico Border This research paper examines the political economy of emerging infectious (EID) surveillance programs. It comprises four case studies - Kenya, Peru, Thailand and the US-Mexico border - and provides lessons learned for US military medical research laboratories collaborating with developing countries. Beneficial techniques for developing countries are discussed, along with an analysis of shortcomings in wildlife surveillance, management of funding constraints and the expansion of laboratory capacity, among others. It argues that in addition to these issues, focus needs to be directed on rural areas that receive less attention because of security constraints.

Cullen S Hendrix (2013) Climate Change, Global Food Markets, and Urban Unrest: This brief discusses why high global food prices give rise to urban unrest in some places and not in others. The author argues that the very features of democracy that make it better suited to address the issues of the rural sector also make democracies more likely to see unrest in times of high food prices. In particular, developing democracies are more prone to urban unrest in times of high prices.

Government of People's Republic of Bangladesh (2005 p.13) Poverty is a broad front. It is about income levels. It is about food security. It is about quality of life. It is about asset bases. It is about human resource capacities. It is about vulnerabilities and coping. It is about gender inequalities. It is about human security. It is about initiative horizons. It is each of these and all of these together.

Cleaver (2005) defines the following factors as important aspects creating chronically poor households in Tanzania: 
life-course4 and dependency; health; poverty and limits of social capital; natural resource use and poverty, and coping strategies.

Dercon (2005:20) comments that too often our assessment or measurement of poverty fails to take vulnerability and risk into account because poverty measurement is done by choosing "a welfare indicator, the identification of the 'poor' via some norm, the poverty line, and an aggregation analysis, he says, takes place in a 'world of certainty' without considering the different risks that people may face and how vulnerable they are to crises throwing them into deeper poverty.

Dercon (2005:21), therefore, defines vulnerability "as the magnitude of the threat of poverty, measured ex-ante, before the veil of uncertainty is lifted".

Wood (2003:455) talks of uncertainty as being: "the determining condition for poor people". He finds that the poorest are those who cannot apply risk management and strategic preparation for the future to ensure their security. Instead the poorest are focused on survival and security in the present.

Rahman and Hossain(1995)Study applied three new approaches to poverty studies in rural Bangladesh. Firstly, they introduced a combination of income and non-income dimensions to include living standard, asset access and institutional capability into their understanding of poverty. This included quality of life variables such as nutrition, living environment, security, crisis-coping capacity and participation, analyzing poverty as a process. Secondly, they focused on specific areas of concern: gender dimensions of poverty, regional variations and seasonal variations in poverty. Thirdly, they highlighted the socioeconomic characteristics of the poor, disaggregating them into categories of non poor, moderate poor and 'hard core' or extreme poor if below certain levels of per capita income based on estimates of calorific requirements7. This study showed that the percentage of the hard core poor in the rural population decreased from $42 \%$ to $24 \%$ between $1987-1990$, showing the dynamic nature of poverty (Sen, 1995).In addition, they found that the majority of the most poor $(84 \%)$ were either landless or functionally landless.

Khan \& Seeley (2005).However, they found that landlessness is not necessarily an indication of chronic poverty, and thus should not be used as criteria of this by agencies assisting the most poor, a point reinforced by the on research on extreme poverty reported.

Timmer (2002) Inadequate and irregular access to food reduces labor productivity and decreases investment in human capital.

Fogel (1991), who reported that increased caloric intake reduced mortality and raised productivity amongst the working poor during the early stages of Western Europe's development. Overcoming hunger and malnutrition is now explicitly recognized in the first Millennium Development Goal.

Timmer 2005; Perry (2005) Macroeconomic stability is especially sensitive to volatility in the agricultural sector In turn, volatility in the agricultural sector tends to be relatively high because of climatic shocks that reduce domestic production and unstable world prices of agricultural commodities. The implication is that these shocks in the agricultural sector, especially food crises, are often the major source of macroeconomic instability in the early stages of development

Barro and Sala-i-Martin (1995) Agricultural growth combined wit appropriate policies can mitigate the effects of these shocks, with benefits to the poorest and most vulnerable.

Hadi(1997) In Bangladesh, female members of rural families do not have opportunities to work in value adding economic activities, except homestead poultry rearing. A rural woman spends her time taking care of her husband, children, elders and other members of her family. Rural women are unable to work outside their home or beyond their homestead because of family restrictions, social and traditional barriers.

Schuler and Riley (1996) The main problem in rural Bangladesh is that most families have insufficient food, clothing, shelter, medication etc. Usually, a rural man works in the fields to produce food for fulfilling basic needs of his family. Given these difficult circumstances, homestead poultry rearing is considered the best way to utilize the capabilities of women to be productive and add value to the household. Rural women have the opportunity to rear poultry in their homestead because it requires minimum land, small amount of capital and uses traditional technology. The market for poultry products is usually within the vicinity of the homestead.

Kishor(1995) Home based poultry is now one of the main sources of income for the rural women of Bangladesh. Poultry also provides meat for the villagers of Bangladesh. Rural women have the discretion to use money earned from the home-based poultry firm. They spend those earnings on the welfare of their children and for special occasions such as, Eid, Durgapuja or Christmas (religious festivals). They buy clothes for their children and for themselves from this income. Profits are often used for educating their children and for buying medicines for family members. This income also helps during family emergencies. The male head of the family works on the agricultural land from dawn to dusk. Hence, home-based poultry rearing provides additional income, which is a very important means for the survival of rural families. Through these traditional poultry rearing practices, rural women are empowered by being involved in the decision making process of their households.

Hashemi (1996). The increased involvement in decision results in the improved status of women in relation to the husband and the family. They can spend money for themselves, which gives them independence to take part in making family decisions. Greater financial independence for rural women increases their bargaining capacity, reduces violence against women, and enables them to gain more influence over decision-making in the family In addition, poultry projects benefit rural women by increasing their food 
consumption and nutrient intake.

Nielsen (2000).In Bangladesh, there is now a growing awareness that rural women can play a more productive role and contribute to the socio-economic development of the country. In general, women in rural areas of Bangladesh have little or no control over their resources and have very little decision-making authority in the family. Hence, involvement in home-based income generating activities like poultry rearing will lead to greater socio-economic empowerment as well as increasing their decision making capabilities. Women can use their additional income to provide their families with a higher standard of living.

Alam(1997). Thus, poultry rearing can deliver significant benefits to rural women in Bangladesh and lead to greater empowerment.

Malhotra \& Mather (1997)In this study we take the position that women's empowerment can be measured by factors contributing to personal, economic, familial, and political empowerment. We also include household and interfamilial relations as we believe these variables significantly affect women's empowerment in Bangladesh.

\section{Objectives of the Research}

The objectives of the Research are-

- To evaluate Rural Development Scheme of Islami Bank Bangladesh Limited.

- To Know the overall pictures of 'Rural Development Scheme' of IBBL

- $\quad$ To Measure the Performance of RDS for last 8 years of IBBL.

- To give recommendations on the basis of findings and analysis of RDS.

\section{Methodology of the Research}

For moving out this paper I had to study the actual banking maneuver especially 'Rural Development Scheme' management of IBBL. For the purpose of the study, data have been collected both from the primary and secondary sources. (a)Primary sources of data: I discussed with the executives \& officials of the IBBL and found the approximate data which have been presented in the research. The study have been conducted through the assistance International Banking Wing (IBW), Head Office of IBBL as per their monitoring / formulating policy issues for enhancing their RDS business through applying modern and technological means. I have been also physically visited to observe the effectiveness of the efforts relating RD effectively and efficiently managed by IBBL. (b)Secondary sources data: A secondary source of information is one that was created later by someone who did not experience first hand or participate in the events or conditions you're researching. For the purposes of a historical research project, secondary sources are generally scholarly books and articles. Also included would be reference sources like encyclopedias.I collected secondary data from the various sources such as annual Reports of 2008-2011 of Islami Bank Bangladesh Ltd.,Islami Bank Bangladesh Limited Websitehttp://www.islamibankbd.com,Bangladesh Bank Web site http://www.bangladeshbank.bd.org,Synopsis and training materials provided by Bangladesh Bank and Islami Bank Training and Research Academy (IBTRA).For tertiary sources of data the researcher has used references from the articles and journals utilized and have also utilized electronic data sources such as the internet.

Data Analysis Techniques: To analysis the study results and investigations the researcher used the following tools and techniques:(a)Pie chart: A pie chart is a circular chart dividend into sectors; each sector shows the relative size of each value.(b)Bar chart: A bar graph displays data visually and is sometimes called a bar chart or a bar graph. Data is displayed either horizontally or vertically and allows viewers to compare items displayed. Data displayed will relate to things like amounts, characteristics, times and frequency etc. A bar graph displays information in a way that helps us to make generalizations and conclusions quickly and easily.(c) Frequency distribution: A table that lists a set of scores and their frequency (how many times each one occurs).

\section{Result and Discussion}

\subsection{Performance of Rural Development Scheme}

The study has determined the variance between expected quantity of variables and actual quantity of variables. The lower the difference, the better the performance of RDS; and the higher the difference, the lower the performance of RDS Statement showing the growth performance of some important parameters.

Table 1. Performance of Rural Development Scheme.

\begin{tabular}{|c|c|c|c|c|c|c|}
\hline Year & Villages & Members & Investment Outstanding (taka in millions) & Cumulative Investment & Deposit & RecoveryRate \\
\hline 2008 & 3700 & 130460 & 570.88 & 4216.77 & 228.7 & $98 \%$ \\
\hline 2009 & 4230 & 163465 & 789.97 & 4216.77 & 322.5 & $99 \%$ \\
\hline 2010 & 4560 & 217445 & 1106.47 & 6033.36 & 459.1 & $99 \%$ \\
\hline 2011 & 8057 & 409575 & 2242.1 & 9303.12 & 724.22 & $99 \%$ \\
\hline 2012 & 10023 & 516725 & 2884.66 & 13969.01 & 910.15 & $99 \%$ \\
\hline 2013 & 10676 & 577740 & 3011.72 & 18768.27 & 1090.26 & $99.03 \%$ \\
\hline 2015 & 12857 & 608703 & 7072.02 & $42,285.23$ & 1924.74 & $99.58 \%$ \\
\hline
\end{tabular}

Source: Annual Reports 2008-2015, IBBL 
Analysis of growth performance in coverage of RDS, RDS is expected to be introduced in the rural areas of the country step by step. It has covered 12857 villages till 2015 with a growth of $13 \%$ over the last 8 years from 2008 to 2015 . The performance of RDS with respect to coverage is most volatile which is reflected through minimum number 75 and maximum number 3497 villages during study period.

\subsection{An overview of the RDS-Model}

Evolution of Interest-free MFIs in Bangladesh is a response to the urge of safeguarding the Islamic way of life in the face of a massive penetration of interest in rural areas through the conventional MFI / NGO approach. One of the glaring features of these initiatives is exclusively indigenous in terms of organization and source of funds which are considered to be building blocks for any effort towards sustainability. Islamic MFIs have come forward very recently as a way of escape from the interest based micro credit program of traditional MFIs and to carry on financial operations with no dependence on subsidies from outside sources. The concept has strong relevance to the Islamic worldview of life. According to this sprit, Islamic MFIs have been implemented integrated rural development and poverty alleviation programs since 1995 (www. concept and ideology rural financing.htm).

The model functions in accordance with Islamic economic principles, and mobilize their resources for entitlement formation by the poor on the basis of Shariah techniques. The target beneficiaries of the programs are mainly; landless poor, wage laborers and marginal farmers aimed at meeting their basic needs and promoting their comprehensive development. RDS has enabled the poorest of the poor to get interest free loan in kind without collateral and saved them from exploitation by both the formal and informal moneylenders who charge interest at a high rate. The institutional mechanism of credit delivery system of RDS is more or less same like Grameen Bank Model and other traditional MFIs. But in case of loan recovery, if a client/ borrower pay full burrowed money in time then he/she is rewarded with rebate3. This system is not followed by traditional MFIs including GB. The growth of membership, amount of loan disbursed/investment assistance, members' savings, recovery etc.

Table 2. Performance "Rural Development Scheme of IBBL" from the year 2012 to 2015 Figure in million /Taka

\begin{tabular}{|c|c|c|c|c|}
\hline Particulars & 2012 & 2013 & 2014 & 2015 \\
\hline $\begin{array}{l}\text { Cumulative } \\
\text { amount of } \\
\text { disbursement } \\
\text { from RDS }\end{array}$ & $13,969.01$ & 18,768 & $24,239.00$ & $42,285.00$ \\
\hline $\begin{array}{l}\text { Outstanding } \\
\text { Investment of } \\
\text { RDS }\end{array}$ & $2,885.00$ & 3,012 & $3,752.00$ & $7,072.00$ \\
\hline $\begin{array}{l}\text { RDS no. of A / } \\
\mathrm{C} \text { holder }\end{array}$ & 350,278 & 321,484 & $492,475.00$ & 608.703 .00 \\
\hline
\end{tabular}

This table shows the cumulative amount of disbursement from RDS, outstanding investment of RDS and RDS no, of account holder was increasing from 2012 to 2015 . As a result the bank makes a profit and no. of account holder.

\subsection{Institutional Development of RDS}

Rural poor are organized in the selected villages under different centers. A center is formed with maximum 40 members. Till 31st December 2015, RDS officials have so far organized 608,703 members under 22,206 centers in 12,857 villages. Out of the total RDS members, $85 \%$ are female.

Table 3. Expansion of RDS in the last 5 years.

\begin{tabular}{|c|c|c|c|c|c|c|c|c|c|c|}
\hline SI. & Part. & 2011 & 2012 & Growth & 2013 & Growth & 2014 & Growth & 2015 & Growth \\
\hline 1 & No.of village & 10,023 & 10,676 & $7 \%$ & 10,751 & $1 \%$ & 11,482 & $7 \%$ & 12,857 & $12 \%$ \\
\hline 2 & No.of center & 18,897 & 21,193 & $12 \%$ & 22,261 & $5 \%$ & 20,8833 & $(6 \%)$ & 22,206 & $7 \%$ \\
\hline 3 & No.of member & 516,725 & 577,740 & $12 \%$ & 492,475 & $(15 \%)$ & 523,941 & $6 \%$ & 608,703 & $16 \%$ \\
\hline
\end{tabular}

Source:AnnualReports2015,IBBL

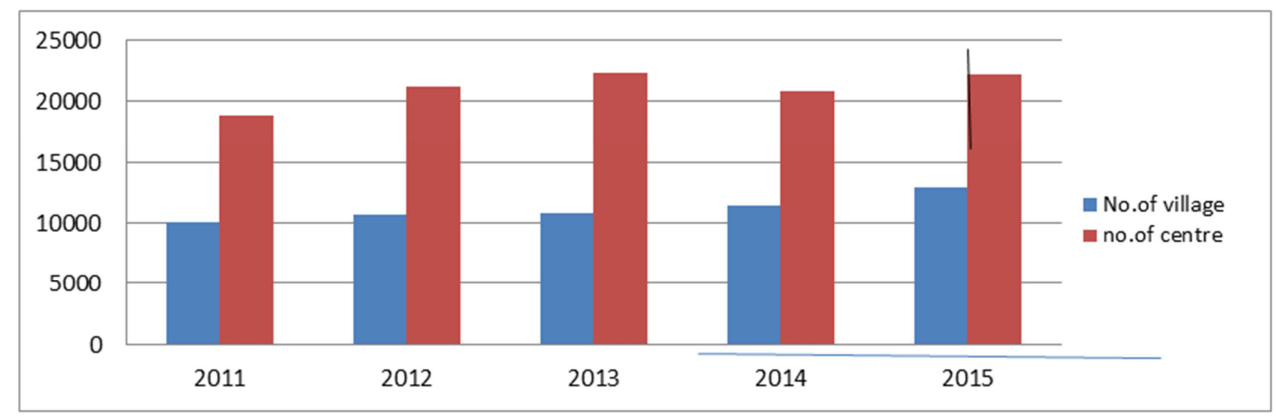

Source: Annual Reports 2015,IBBL

Fiqure 1. Institutional Development. 


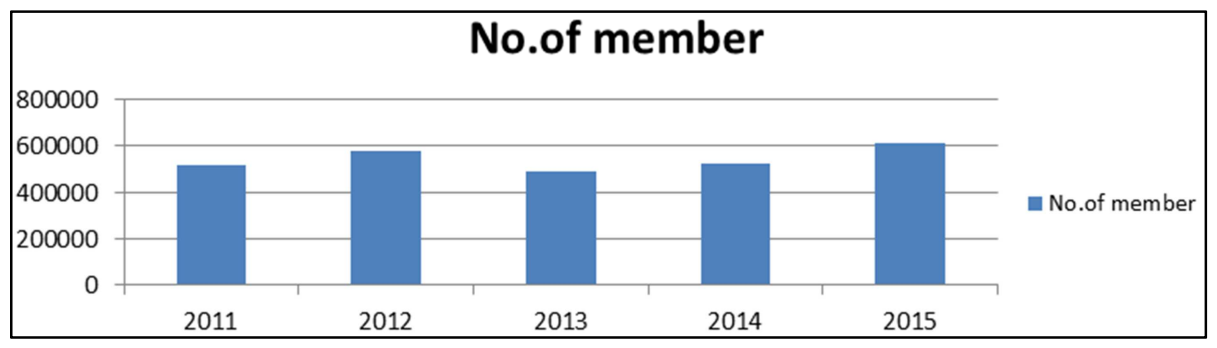

Source: Annual Reports2015,IBBL

Fiqure 2. RDS member.

This above graph shows that the no. of village was increasing from 2011 to 2015 . Also the no. of center was increasing 2011 to 2013 and 2015 but 2014 was decreasing from 2012. As a result the bank improved RDS member have been provided with collateral-free micro-investment facilities under the scheme in different agriculture and off farm activities up to the maximum amount of TK. 50,000/- per client.

Table 4. Sector-wise Investment inception.

\begin{tabular}{llll}
\hline SI. & Sector & Amount(mill.) & Percent(\%) \\
\hline 1 & Crops\&othercultivation & 1,556 & $22 \%$ \\
2 & Agro-machineries & 71 & $1 \%$ \\
3 & Nursery & 141 & $2 \%$ \\
4 & Livestock & 990 & $14 \%$ \\
5 & Poultry & 71 & $1 \%$ \\
6 & Fisheries & 354 & $5 \%$ \\
7 & Ruraltransport & 637 & $9 \%$ \\
8 & Ruralhousing & 919 & $13 \%$ \\
9 & Off-farmactivities & 2334 & 335 \\
& Total & 7072 & $100 \%$ \\
\hline
\end{tabular}

Source: Annual Reports 2015,IBBL

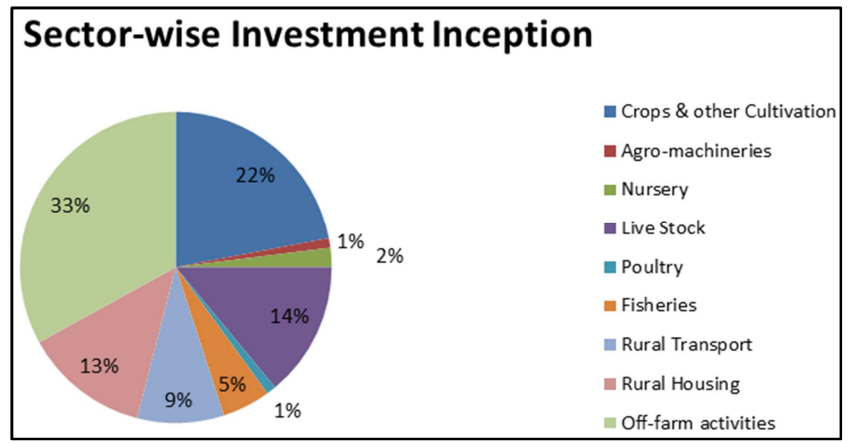

Source: Annual Reports 2015,IBBL

Fiqure 3. Sector-wise investment inception.

The bank was more invest in off-farm activities, crops \& other cultivation then other sector. Crops and other Cultivation 22\% ,agro-machineries- $1 \%$,nursery-2\% ,Live stock-14\% ,poultry-1\% ,fisheries-5\% ,rural transport$9 \%$,rural housing-13\%,off-farm activities-33\%.

\subsection{Performance of Rural Development Scheme up to June 2015}

Islami Bank Bangladesh Limited launched its Rural Development Scheme (RDS) in 1995. In the mean time, 144
Branches of the Bank have been operating the activities of the Scheme in their respective areas. These Branches are working among the poor in 10,754 villages covering 1,199 unions less than 296 Thana's of 61 districts of the country. Present number of members is 5, 01,941 since beginning the scheme. The members are provided investment facilities an amount of BDT $28,100.10$ million ( $\$ 407.25 \mathrm{~m}$ ) up to $30-06-$ 2015 against which the outstanding was BDT 4,320.41 million $(\$ 62.61 \mathrm{~m})$. Rate of recovery of the Scheme is more than $99 \%$.

Besides the regular investment program, we have provided with hand tube-well and sanitary latrine to the successful RDS members on guard from the fund given by Islami Bank Foundation. A total of 7,946 tube-wells \& 4,322 sanitary latrines have so far been distributed at a cost of BDT 15.84 million (\$ $0.23 \mathrm{~m})$ \& BDT 4.76 million (\$ $0.07 \mathrm{~m})$ respectively up to the said date.

\section{Findings}

- $\quad$ RDS can be differentiated from any traditional microcredit programs with respect to target group, selection criteria, profit sharing basis, value generation, low charge.

- Insufficient for Agro-machineries and rural transport' maximum loan amount.

- $\quad$ Nursery, poultry, fishery sector investment, coverage, and deposit. This has been found very robust across the years under study.

- RDS has been found to exert a positive and significant influence in gross monthly income of borrowing members; but the income is found not significantly associated with family size, size of assets, education. This means that RDS cannot influence these socio-economic factors. This may be because of lower size of investment, forward lending, lake of opportunities etc.

- $\quad$ RDS is expected to be introduced in the rural areas of the country step by step. It has covered 12857 villages till 2010 with a growth of $13 \%$ over the last 8 years from 2003 to 2010 .

- This program has specific criteria of selecting rural people for making member of the group as well as of centre and granting them with micro-credit. RDS has registered growth of $17.75 \%$ in number of members 
over seven years from 2003 to 2009 understudy.

- $\quad$ RDS provides credit in the form of assets on profit sharing basis; although it charges lower profit rate of $10 \%$ subject to the rebate of $2.50 \%$ in the case of current borrower members.

- It has been observed that the investment performance of RDS is most favorable in the year 2006 and 2007; and most unfavorable in the year 2008. The most unfavorable position in the year 2008 can be attributed to the global financial meltdown as well as activities of the program.

- The members of RDS are open Mudaraba Saving Account (RDS) in the name-Individual and Centre. Each member has to deposit minimum Tk. 20 and minimum Tk. 5 to Mudaraba Saving Account Individual and Maduaraba Saving Account-Centre compulsorily.

- $\quad$ RDS has accomplished a phenomenal growth in Deposits to the extent of $28.51 \%$ over the 7 years understudy. This growth also indicates that RDS is growing in terms of members, investment and sustainability of borrowing members for longer period with the bank.

- This indicates two important aspects of sustainability of RDS; efficiency of monitoring \& controlling authority of RDS, and the capacity of borrowing members to repay out of earnings generated from farm and non-farm activities.

- $\quad$ The recovery rate has been found $98 \%$ to $99.03 \%$, indicating the ability of members as well as strong RDS mechanism in recovery of dues.

\section{Recommendation}

Though Islamic bank is comparatively superior to conventional interest based bank from various aspects like abolition of interest based loan market, no fixed cost of capital, stimulation for accelerating saving and capital formation, efficient allocation of investment, production and profit, easy recovery of investment capital, lower inflationary situation, etc. Islami bank has to fight for several obstacles in case of harmonious operation. Here I have tried to locate some vivid hindrance and suggested accordingly.

- $\quad$ Any kind of bank Shariah based or interest based has to operate under regulatory environment prepared and approved by the government. There are conflicts between Islami Shariah and general Government rules and banking law. That's why Islami bank does not get the opportunity and help from the running law of government.

- Lending procedure of IBBL need to take less time for their customer's investment section. The bank should try to sanction investment within one month or less.

- The bank should be flexible to the clients for the investment sanction.

- The bank should analyze customer's financial statement and their management Capacity.
- The techniques of supervision \& monitoring need to be ensured before clients failing to repay the investment.

- The authority of RDS should increase the size of investment in order to cope with the change in value of currency because of inflation and other economic reasons

- RDS should project their volume of activities for future; then all parties involving in managing RDS should be assigned and held responsible for the job assigned at the beginning of the year. That is, the performance of RDS should be subject to Balanced Score Card System.

- $\quad$ RDS with its differentiated features can lock more market share in the country if it comes out with more generous policy like selection of people not on religions basis.

- Agricultural investment should be increased in this bank.

- The bank should be flexible about collateral for giving advance to the client's

- The authority of RDS should increase the size of investment in order to cope with the change in value of currency because of inflation and other economic reasons.

- RDS should project their volume of activities for future; then all parties involving in managing RDS should be assigned and held responsible for the job assigned at the beginning of the year. That is, the performance of RDS should be subject to Balanced Score Card System.

- RDS with its differentiated features can lock more market share in the country if it comes out with more generous policy like selection of people not on religions basis.

- The repayment should be balloon basis. That is, repayment system should start at least after one month of taking loan, and should be based on the nature of cash flow being generated from farm and non-farm activities like seasonal cash flow and regular cash flow

- The study recommends that RDS activities be extended towards hardcore poor, especially for widows and divorcees. Monitoring and supervision should be strengthened, while more ethical and moral motivational programs have to be undertaken for both field supervisors and clients to reduce shariah violation. The program can be replicated in other rural areas of Bangladesh in order to accelerate economic activities of the poor.

- The members of the RDS have given many interesting and important suggestions for the increasing the number of clients. Perhaps very consistently, the members have suggested that the IB should increase the volume of credit. Through experience they were of the opinion that peoples' demand for money was very high. The lending 
institutions gave fell short of their demands. Even the amount of loan/investment given by the IB fell short of their demands. Even the amount of loan/investment given by the IB fell short of the amounts given by the other institutions, particularly, GB, ASA and BRAC. Given the opportunities for proper utilisation, the bank should also provide more than one type of loans (general loans, housing loans etc

\section{Conclusion}

Rural development scheme assumes very important position in the social portfolio of IBBL. It is not an exception in case of Islami Bank Bangladesh Limited. Rural Development Scheme is a scientific and shariah based micro credit system. The basic objective of the program is to graduate the poor class of the society from the poverty clutch through getting them involved into the different income generating activities by providing loans and teachings of Islam. This program is in line with social and cultural values of muslim ummah of the country. This program is expected to give a breakthrough in the intervention of poverty trap of the country if suggestions put forwarded are implemented. RDS in Bangladesh as well to achieve its mission to spread the Islamic Banking throughout the world economy system. I also think that there is bright future waiting for the Islami banking in Bangladesh.

\section{Annexure}

\section{Annexure-1}

Questionnaire

"Rural Development Scheme: A Case Study on Islami Bank Bangladesh Limited". For the successful completion of this research; I need some information from you. I wish your kind cooperation and assistance. I can give the assurance that all information you would kindly give me will be used for research purpose only.

Name

Age Occupation

1. What is your profession?

A. cultivator farmer B. Poultry farmer C. Rural transporter D. Nursery

2. Which of the following income level do you belong?
A. Below 12000
B. $12000-20000$
C. $20000-40000$
D. 40000- above

3 . How much they cooperative with you?
A. Bad
B. So
C. Good
D. Very Good

4. What is the satisfaction level of IBBL performance?
A. High
B. Low
C. Average
D. None

5. Do you think taking loan process is simple and extensive?
A. Yes
B. No
6. Do you agree that RDS scheme help you to develop?
A. Yes
B. No

\section{References}

[1] RDS Manual (2008), Islami Bank Bangladesh Limited, Bangladesh.

[2] Manuals (2002-2008). GB/BRAC/ASA/PROSHIKA/CARE /ODEC/ACTIONAID, Dhaka: Bangladesh

[3] Chowdhury, M. A. M. (2005), the Role of Islamic Financial Institutions in Resource Mobilization and Poverty Alleviation in Bangladesh: An Empirical Study of Rural Development Scheme of IBBL.

[4] IBBL, A.R.( 2009) Performance of Rural Development Scheme, Islami Bank Bangladesh Limited Dhaka, Bangladesh.

[5] IBBL, A.R.( 2007) Performance of Rural Development Schem, Islami Bank Bangladesh Limited Dhaka, Bangladesh.

[6] Mizanur, M., Rahmana, M. Jafrullahb and A.T. Islamc (2008). Rural Development Scheme Bangladesh Limited (IBBL): Assessment Challenges. IIUM Journal of Economics and Management, 16(2): 139-163.

[7] Parveen, J.A.(2009),Sustainability Issues Of Interest-Free Micro-Finance Institutions In Rural Development And Poverty Alleviation. The Bangladesh Perspective. Theoretical and Empirical Researches in Urban Management, 2(11).

[8] Islami Bank, 24 Years of Progress.(2007), Islamic Bank Bangladesh Limited (IBBL), p.35

[9] Rahman M.M. (2006), Impact of Rural Development Scheme (RDS) of IBBL on the Rural Poor's

[10] Livelihood in Bangladesh(2007),Islamic bank Training and Research Academy (IBTRA), Mohammadpur Dhaka, pp.-1-50.

[11] Laura Ryser and Greg Halseth.(2010 ),Community Development Institute, University of Northern British Columbia.Geography Program, University of Northern British Columbia Article first published online: DOI: 10.1111/j.17498198.2010.00321.x

[12] Robert Chapman S.P and Tom Slaymaker M.S(2002), Overseas Development Institute (ODI) V-0-85003P-619-4

[13] Sophal Ear.(2012) ,Center for Contemporary Conflict (CCC) Volume:2012 Issue:14 
[14] Cleaver, F.(2005),The Inequality of Social Capital and the Reproduction of Chronic Poverty.

[15] World Development, 33(6): 893-906.

[16] Cullen S Hendrix.(2013), Robert S Strauss Center for International Security and Law Issue:7

[17] Dercon, S.(2001). Assessing Vulnerability, Oxford, Oxford University of Economics pp. 79. http://www. economics. ox.ac. uk/members /stefan. dercon/ assessing\%20vulnerability.pdf

[18] Dercon, S.(2005). Vulnerability: a micro perspective, ABCDE Conference,

[19] http://www.economics.ox.ac.uk/members/stefan.dercon/vulner ability.pdf, Amsterdam,April 2005.

[20] Government of People's Republic of Bangladesh(2005 p.13)

[21] Wood, G. and Salway, S.(2000),Introduction. Securing Liveihoods in Dhaka Slums. Journal of International Development, 12(5): 669-688.

[22] Rahman, H., Z. and Hossain, M.(1995),Rethinking Rural Poverty: Bangladesh as a case study.Sage Publications, London, New Delhi.

[23] Khan, I.A. and Seeley,J .(2005).Making a Living: The Livelihoods of the Rural Poor in

[24] Bangladesh. University Press Ltd., Dhaka.

[25] Fogel, R. W. (1991), “The Conquest of High Mortality and Hunger in Europe and America: Timing and Mechanisms." In Favorites of Fortune: Technology, Growth, and Economic Development since the Industrial Revolution. Ed. P. Higonnet, D. S. Landes, and H. Rosovsky.Cambridge, MA: Harvard University Press.

[26] Timmer, P.(2005),“Agriculture and Pro-Poor Growth: What the Literature Says." Draft paper, Agricultural and Rural Development Dept., World Bank, Washington, D.C.
[27] Barro, R. J. and X. Sala-i-Martin.(1995), Economic Growth. New Yorkl: McGraw-Hill.

[28] Hadi, A (1997), The NGO intervention and women's empowerment - the Bangladesh experience, International Seminar on Women Empowerment, RFSU (Swedish) Association for Sexual Education), Stockholm, April

[29] Kishor, S (1995), Autonomy and Egyptian women: Findings from the 1988 Egypt demographic and health survey, Macro International, Inc. (Calverton, Md.).

[30] Hashemi, S.M, (1996), Rural credit programs and women's empowerment in Bangladesh, World Development, vol. 24, no. 4, pp. 635-653

[31] Schuler, S, \& Riley, A (1996), Rural credit programs and women's empowerment in Bangladesh, World Development, vol. 24 , no. 4 , pp. $635-653$

[32] Nielsen, H (2000), Food and nutrient intake among females in rural Bangladesh: How does a poultry project benefit women and girls. Master's Thesis, Research Department of Human Nutrition, The Royal Veterinary and Agricultural University, Copenhagen, November.

[33] Alam, J (1997), Impact of smallholder livestock development project in some selected areas of rural Bangladesh, Livestock for Rural Bangladesh, vol. 9, P.89

[34] Malhotra, A \& Mather, M (1997), Do schooling and work empower women in developing countries?, Gender and Domestic Decisions in Sri Lanka. Sociological Forum, vol.12, no. 4, pp. 599-630.

[35] Annual report of Islami Bank bangladesh Limited 2006-2012.

[36] www.IBBLbd.com

[37] www.bangladesh-bank.org

[38] www.wikipedia.com

[39] www.islamibankbd.com 